\title{
FIRST-ORDER LEVELING REVEALS ANOMALOUS, InTERSEISMIC, CONTRACTILE, Transient STRAIN ACross Teton Normal FAult, 1988-2001, Grand TETON NATIONAL PARK, WYOMING
}

\author{
A. G. SYlVESTER $\downarrow$ UNIV. CALIFORNIA $\uparrow$ SANTA BARBARA \\ R. B. SMITH $\downarrow$ WU LUNG CHANG $\downarrow$ UNIV. UTAH $\downarrow$ SALT LAKE CITY \\ C. S. HITCHCOCK \WM. LETTIS \& ASSOC., INC. \ WALNUT CREEK $\downarrow$ CA \\ J. O. D. BYRD $\downarrow$ ANADARKO PETROLEUM $\downarrow$ HOUSTON $\uparrow$ TX
}

\section{$\downarrow$ ABSTRACT}

As part of a comprehensive neotectonic study of interseismic behavior of active faults, we have done six first order leveling surveys of 50 permanent bench marks in a $22 \mathrm{~km}$-long base line across the Teton fault to characterize its interseismic behavior between 1988 and 2001. This $55 \mathrm{~km}$-long normal fault extends along the eastern base of the Teton Range, exhibits up to $30 \mathrm{~m}$ of post-glacial offset, and has one the highest rates of Holocene slip of any fault in the Basin-Range. It is seismically dormant at the M2+ level, however, and presently lies in the center of a $50 \mathrm{~km}$-long seismic gap. Results of five of the six levelings are remarkably similar and suggest that the alluvium-filled valley of northern Jackson Hole (hanging wall) subsided 6-8 mm relative to bedrock of the Teton Range (footwall) relative to the 1989 survey. Height changes were insignificant from 1989 to 1993. In 1997, however, a $2 \mathrm{~km}$-wide zone adjacent to the fault rose $12 \mathrm{~mm}$ relative to the 1993 survey, and then dropped $16 \mathrm{~mm}$ by the 2001 leveling. This zone coincides with an area of low topography characterized by lakes ponded along the fault and south-flowing streams parallel to the range front, rather than eastward away from the range. This subsidence zone records hanging wall subsidence related to long term faulting. The 1997 uplift of the valley floor and subsidence zone may reflect an unexpected, reverse loading and
\end{abstract}

local crustal shortening between 1993 and 2001. Campaign GPS surveys (1987 to 2000 , only briefly summarized in this report) support this hypothesis, indicating that the principal direction of horizontal shortening was locally E-W perpendicular to the fault, and that crustal shortening occurred in the period 1995-2000. Regionally during 1987-1995, subsidence and shortening characterized deformation of the Yellowstone caldera when GPS recorded uplift and extension across the Teton fault, only $30 \mathrm{~km}$ to the south. During 1995-2000, subsidence slowed or ceased for much of the caldera, whereas the overall GPS vectors across Jackson Hole were directed west with almost $2 \mathrm{~mm} / \mathrm{yr}$ of E-W motion (N. America fixed). This shortening strain field implies that the regional stress field was compressional normal to the fault at the time of the 2000 GPS survey. The return of the 2001 leveling signal to pre-1997 values suggests that the strain reversed or relaxed, and that the 1997 leveling anomaly was a contractile strain transient that passed across the fault probably between 1995, when the strain pattern at Yellowstone caldera changed, and the 2000 GPS survey but before the 2001 leveling. Preliminary elastic dislocation models indicate 10-20 mm reverse slip at a depth of 1-2 km. Alternatively the observed leveling changes may reflect a complex combination of other processes including local poroelastic effects, or nearfield drag of the hanging wall as it subsides overall in farfield extension. 


\section{INTRODUCTION}

The long range purpose of this project is to determine the vertical strain along the Teton normal fault, if any, that occurs in the absence of detectable earthquakes on the fault. The method of study is classic spirit leveling of 50 permanent bench marks in an irregular line $17 \mathrm{~km}$-long across the fault (Fig. 1). The bench marks were emplaced and surveyed in 1988 (Byrd and Smith, 1989), and subsequent surveys of it were done in 1989, 1991, 1993, 1997, and 2001. We line extended eastward $6 \mathrm{~km}$ to the foot of the Gros Ventre Mountains in 1993 and resurveyed again only in 1997.

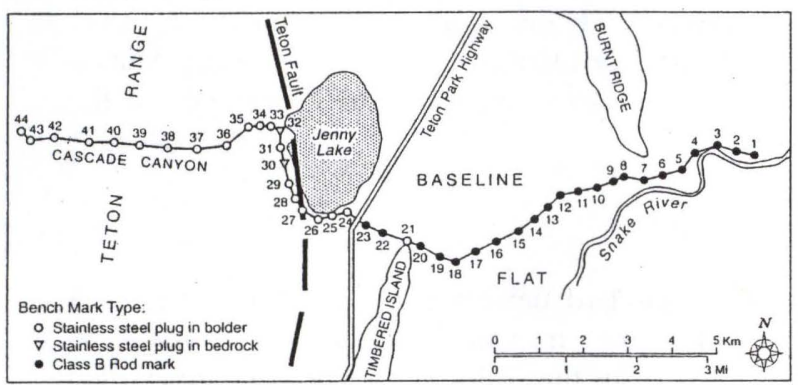

Figure 1. Location of Teton leveling line relative to the Teton fault (heavy line)

The objective of the study is to learn how active faults behave during interseismic time, that is, in the times between their large earthquakes. A handful of faults slip a few millimeters to a few centimeters a year by a process called creep that occurs aseismically - without earthquakes, or least not with earthquakes with magnitudes greater than 2 (Wesson, 1988). Such a fault is the San Andreas fault in California, the middle $140 \mathrm{~km}$ of which slips right-laterally up to $34 \mathrm{~mm} / \mathrm{yr}$, whereas most of the remainder of the fault is locked. Other faults that also creep are few but are also strike-slip faults. Why should that be so? Is it simply because creep is so difficult to prove and that no one has ever looked at other kinds of faults, especially and including normal faults like the Teton fault?

The initial purpose of the Teton leveling line was to establish a baseline to gauge the pattern of vertical deformation associated with the next large earthquake on the fault, even if that earthquake may not occur for several hundred years. Thus each benchmark was intended to have a half life of 200 years, and from patterns of bench mark height changes along the line, one should be able to calculate the shape of the fault at depth. The 1989 survey w as done to ascertain the stability of the bench marks, but when that survey was compared with that in 1988, height changes were revealed within the line near the fault that were completely unexpected and led us to conclude that about $10 \mathrm{~cm}$ of movement - valley up, Teton Range down - had occurred in the year between the two surveys (Sylvester et al, 1991). That conclusion is counter-intuitive - a normal fault should slip in such a way that the mountains rise and the valley subsides - and led us to do additional surveys to monitor the fault's behavior over a longer period of time.

\section{Bench Marks}

In instances where one expects to measure vertical displacements of only a few millimeters, it is imperative that bench marks be exceedingly stable, that surveying procedures be as precise as possible, and that the accuracy of each survey be as high as possible.

Two kinds of bench marks comprise the Teton leveling line: 1) Class B rod marks (Federal Geodetic Commission, 1984), and short, stainlesssteel rods affixed in holes drilled into large, stable boulders or bedrock. Analyses of their relative stability have been published by Karcz et al. (1989). The best indication of the stability of the bench marks is their insignificant changes in height relative to one another from survey to survey. With exception of bench marks GT18 and GT34, all bench marks differ in their heights relative to one another by less than a few tenths of a millimeter (Figure 2), that is, well within the accuracy of the surveying method.

GT18 appears to have been stable until 1997 when it dropped about $1.5 \mathrm{~mm}$ relative to GT17. Whereas all Class B rod marks are surrounded by pipe and backfilled with gravel nearly to the collar of the pipe, the GT18 rod stands about $30 \mathrm{~cm}$ free above the base of the hole in the pipe. A very large tree had fallen directly onto the boulder containing GT34 after the 1997 survey but before the 2001 survey, and that event may have dislodged the boulder sufficiently to account for the $1.5 \mathrm{~mm}$ decrease in its height relative to its neighbors.

\section{Standards}

A Wild N3 tilting level and a Wild NAK2 automatic level with optical micrometer, with matching pairs of strut-supported, double-scale, Wild GPL-3 invar leveling rods, 4003A/B and 6477A/B, respectively, were used throughout each survey. The leveling rods were calibrated annually by laser interferometry at the US. Navy Gage and Standards Laboratory. The leveling instruments also received routine, factory-authorized maintenance and 
adiustment before each survey.

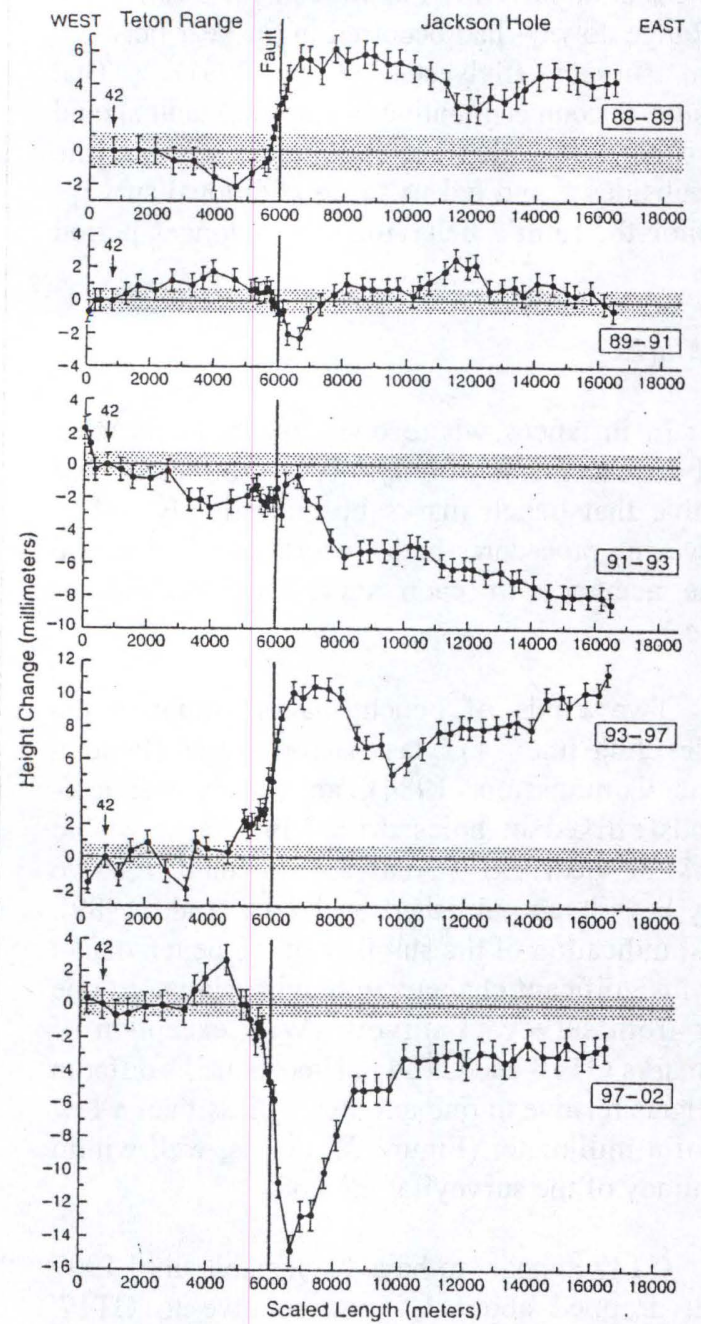

Figure 2. Observed height changes relative to the previous survey. Line length is scaled distance resulting from projection of individual bench marks in the nonlinear arrangement of the level line into straight line that passes through end points of line. Bench mark GT42 at west end of array is arbitrarily held fixed for both surveys. Precision and standard deviation for each survey summarized in Table 1.

\section{Survey Methods}

We have taken exceptional care to perform the leveling according to intrumental and procedural specifications prescribed for First Order, Class I leveling (Federal Geodetic Commission, 1984).

The 2001 leveling, like each of the previous five surveys, was performed by closing a series of double-run sections from 0.5 to $1.5 \mathrm{~km}$ in length that consisted of forward and backward observations of all bench marks within the section. Sight lengths from instrument to rod were balanced, were less than $25 \mathrm{~m}$, and averaged $13 \mathrm{~m}$. The instrument was always shaded, and a temperature reading was taken at the instrument for nearly every shot at a height from 1 to $1.5 \mathrm{~m}$ above the ground surface, although the temperatures were not used in data adjustment. The A-rod was always placed on a permanent bench mark to minimize errors due to differences in rod length. Turning plates were used at turning points. To minimize personnel errors, each instrument man shot the backrun of his forerun.

It is noteworthy that all six surveys have been done in August and early September to minimize thermal and climatic differences that may introduce systematic or random errors. The same instruments and the same rods, moreover, have always been used to survey the same line segments again to minimize errors due to differences in the standards.

\section{Survey Accuracy}

The standard deviation $(S)$ per kilometer for a one kilometer measured distance $L i$ may be calculated from the following relation (Kahmen and Faig, 1988, p. 382):

$$
S=\sqrt{ } \frac{1}{2 \mathrm{n}} \Sigma \frac{\mathrm{d}^{2}}{\mathrm{~L}_{\mathrm{km}}}
$$

where $\mathrm{n}$ is the number of individual survey segments distances $L 1, L 2 \ldots L n$ in the entire line, and where $d i$ are the differences between forward and return surveys in each segment. The mean value $(\sigma)$ from forward and return measurements for the entire line is given by the following equation (Kahmen and Faig, 1988, p. 382):

$$
\sigma= \pm \frac{S}{\sqrt{ } 2}
$$

The relevant values may be plugged into these equations to calculate the accuracy for each of the six leveling surveys (Table 1).

Table 1. Standard deviation $(S)$ and mean value $(\sigma)$ per kilometer for a one kilometer measured distance $L$ for each leveling survey of the Grand Teton leveling line.

\begin{tabular}{|c|c|c|c|c|c|c|}
\hline & 1988 & 1989 & 1991 & 1993 & 1997 & 2001 \\
\hline$S$ & $0.74 \mathrm{~mm}$ & $0.67 \mathrm{~mm}$ & $0.58 \mathrm{~mm}$ & $0.53 \mathrm{~mm}$ & $0.57 \mathrm{~mm}$ & $0.72 \mathrm{~mm}$ \\
\hline$\sigma$ & $0.52 \mathrm{~mm}$ & $0.47 \mathrm{~mm}$ & $0.41 \mathrm{~mm}$ & $0.37 \mathrm{~mm}$ & $0.40 \mathrm{~mm}$ & $0.44 \mathrm{~mm}$ \\
\hline
\end{tabular}

Inasmuch as the results according to equations (1) and (2) match so closely for each survey and for all 
surveys, we may conclude that the surveys are of comparable precision, and that systematic errors have been properly eliminated in each survey. The standard deviations of each survey are well within the prescribed requirements for Class 1B ("first order") surveying), which is equivalent to $1 \mathrm{mmx} \mathrm{L}^{-1 / 2}$ (where $\mathrm{L}$ is the one-way length of the line in kilometers), as compared to "first order precision" of $2 \mathrm{~mm} \mathrm{x} \mathrm{L}^{-1 / 2}$, and "second order precision" of $5 \mathrm{~mm} \mathrm{x} \mathrm{L}^{-1 / 2}$ (Federal Geodetic Commission, 1984).

We searched our data for height dependent errors using the method of Stein (1981) and found such errors are lacking, probably because of the short, balanced sights $(<25 \mathrm{~m})$ we generally use to minimize refraction effects (Castle et al., 1994). The double runs precluded field blunders. National Geodetic Survey model refraction error corrections were applied to the first four surveys but have not been incorporated in the compiled results, because they degrade First Order, Class I data (Castle et al., 1994).

\section{Observed Height Changes}

The principal changes from one survey to the next are relatively minor, but the 1988 and 1997 survey data are anomalous relative to the other four surveys (Figure 2). Between 1988 and 1989 Jackson Hole (hanging wall) rose about $7 \mathrm{~mm}$ compared to the core of the Teton Range (Figure 2). This sense of displacement is opposite to that expected for loading associated with normal faults where the hanging wall should subside relative to the footwall. Between 1989 and 1991, height changes were at or near the standard deviation of the measurements, except in the hanging wall adjacent to the fault and in the central part of the line on the hanging wall. That the footwall block tilted slightly eastward is a permissive but tenuous conclusion. The sense of the observed height change bears no evident relation to that of the topographic profile, indicating that the data are not contaminated by refraction errors.

In 1993, the entire line subsided nearly to the 1988 level with the suggestion of normal separation within the west edge of the hanging wall rather than at the fault itself. In 1997, the hanging wall rose $10 \mathrm{~mm}$ relative to 1993 (Figure 2). In 2001 relative to 1997 , the line subsided up to $15 \mathrm{~mm}$. Thus, relative to 1989 , the hanging wall rose and fell several millimeters in several episodes (Figure 2). The footwall height changes are minimal among all but those bench marks within $1000 \mathrm{~m}$ of the fault (Figure 2).
The observed height changes correlate spatially with the Teton fault (Figure 2). The location of the Teton fault trace near the center of the zone of greatest height change and the greater magnitude of hanging-wall uplift suggest that the fault and footwall rocks influence the observed pattern of uplift. The apparently systematic height changes of bench marks up to $2 \mathrm{~km}$ into the footwall, however, suggest that the mechanism driving the uplift may also involve the footwall rocks adjacent to the Teton fault.

Analytic hydraulic modeling and boundary element modeling of the leveling data (not presented and discussed here) suggest that the observed height changes may be due to a combination of shallow, $<2$ $\mathrm{km}$, and deep, $>10 \mathrm{~km}$, slip on a single east-dipping dislocation. Displacements of $4.0 \mathrm{~cm}$ and $7.0 \mathrm{~cm}$ at depths of 0.5 to $1.25 \mathrm{~km}$ and 10 to $12 \mathrm{~km}$, respectively, on a $60^{\circ} \mathrm{E}$ dipping normal fault reproduce the observed height change patterns in the footwall and hanging-wall quite well for 1988 to 1989. A $12 \mathrm{~km}$ thick elastic layer $(V=0.25$, Young's modulus $(\mathrm{E})=3 \times 10^{10} \mathrm{~Pa}$ ) overlying a slightly plastic $\left(\mathrm{V}=0.35, \mathrm{E}=3 \times 10^{9} \mathrm{~Pa}\right)$ layer was invoked in this best-fit model. A number of other combinations of displacement, depth of displacement, elastic layer thickness, V, and E were also tested and yield generally similar results. Models with $75^{\circ} \mathrm{E}$, $45^{\circ} \mathrm{E}$ and $30^{\circ} \mathrm{E}$ dipping faults generated results similar to the $60^{\circ} \mathrm{E}$ models with the exception that the theoretical pattern of hanging-wall and footwall subsidence yielded a poorer fit to the observed data. Various listric fault geometries were also tested and yielded deformation profiles that closely matched the observed data.

\section{$\downarrow \quad$ GPS SURVEY RESULTS}

Three campaign GPS surveys (1987, 1995, and 2000) centered on Yellowstone National Park, but with several stations in and around Grand Teton National Park, provide insight into the nearfield and farfield strain. Regionally during 1987-1995, when subsidence and shortening characterized deformation of the Yellowstone caldera only $30 \mathrm{~km}$ to the north of the Teton leveling line, GPS surveys recorded uplift and extension across the Teton fault (Figure 3). During 1995-2000, subsidence slowed or ceased over much of the caldera, whereas the overall GPS vectors across Jackson Hole were directed westward with almost $2 \mathrm{~mm} / \mathrm{yr}$ of ESE-WNW motion (N. America fixed). This strain field would imply that the regional stress field was compressional across the fault at the 
time of the 2000 GPS survey. That time period, 19952000, contains the 1997 leveling, which indicates hanging wall uplift more strongly than any of the other leveling episodes, except 1988 to 1989 . The return of the 2001 leveling signal to pre-1997 values suggests that the E-W compressive stress reversed or relaxed, and that the 1997 leveling anomaly was a shortening strain transient that passed across the fault probably between the 1995 and 2000 GPS surveys, when the strain pattern at Yellowstone caldera changed from subsidence to uplift, but before mid2001 when the leveling profile decreased to pre-1997 levels.

\section{Vertical Changes}

Yellowstone caldera

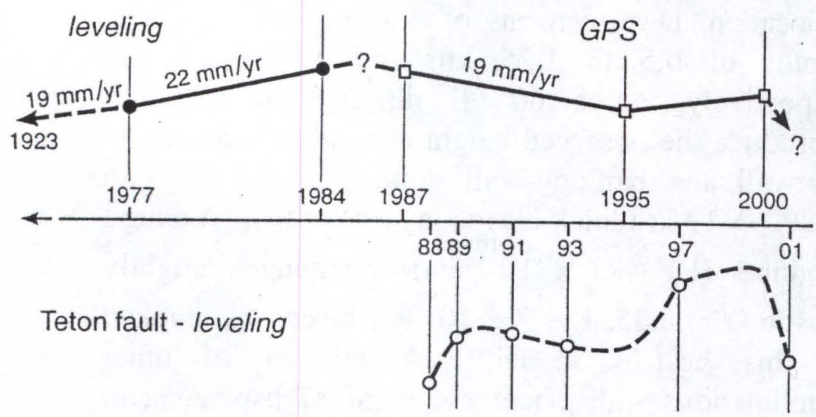

Figure 3. Relation of Yellowstone caldera uplift and subsidence (1923-2000) to uplift across Teton fault 1988-1001)

Shortening strain transients have been recognized elsewhere in the Basin and Range province wherein deformation occurs as a series of blocks undergoing non-continuum extensional deformation (King et al., 1994). Discrete deformation is concentrated at the eastern and western boundaries of the Basin and Range (Thatcher et al., 1999). Internally the deformation is largely continuous, but locally, some blocks are translating northwestward faster than adjacent blocks (Wernicke et al., 2000), so that parts of the Basin and Range are shortening, while the overall deformation regime is extensional. Likewise, all of the stations translated west-northwestward in 1995-2000, but the block east of the Teton Range translated faster than that to the west, resulting in local shortening and reverse slip across the Teton normal fault.

\section{$\downarrow \quad$ CONCLUSIONS}

Comparison of repeated First Order, Class II surveys of a $22 \mathrm{~km}$-long leveling line across the central part of the Teton fault indicates that aseismic, hanging-wall uplift characterized the near-field strain across the fault during the 1988-2001 period. Maximum hanging-wall uplift of $7.9 \pm 0.4 \mathrm{~mm}$ and footwall subsidence of as much as $1.4 \pm 0.4 \mathrm{~mm}$ occurred across a $3.1 \mathrm{~km}$-wide zone bracketing the Teton fault in that time. Three sets of GPS measurements 1985-2000 indicate that crustal shortening occurred across the fault, causing thereby reverse slip on a normal fault.

A combination of hydraulic and aseismic fault-creep mechanisms is proposed to account for the observed height changes. The abrupt $7.2 \mathrm{~m}$ increase in the level of Jackson Lake between 1988 and 1989 may have imposed unique hydraulic conditions in the vicinity of the leveling line. Analytical elastic-hydraulic model results suggest that these hydraulic fluctuations could have caused up to $\sim 11 \mathrm{~mm}$ of poroelastic vertical expansion of a $600 \mathrm{~m}$ thickness of saturated unconsolidated deposits in vicinity of the leveling line.

The validity of the hydraulic and boundary element model results is restricted by the paucity of subsurface hydrologic, elastic, and fault geometry data in vicinity of the level line. In addition, the combination of relatively anomalous hydraulic conditions prior to the 1988 and 1989 surveys may limit confident use of either survey as a datum for evaluating long-term contemporary deformation.

The likelihood of deep-seated aseismic creep having occurred on the Teton fault is greatly reduced if hydraulic mechanisms contribute a measurable effect on the leveling line. In fact, the average $4 \mathrm{~mm}$ subsidence of bench marks farther than $2 \mathrm{~km}$ east of the fault in 1991 may have been caused by deflation attributed to poroelastic effects in unconsolidated deposits, whereas deformation within $2 \mathrm{~km}$ of the Teton fault was a result of shallow aseismic creep on the fault.

The modeling results imply that normal dipslip dislocation of $2.5-4.5 \mathrm{~cm}$, at depths from $0.25-$ $1.25 \mathrm{~km}$ on a $30^{\circ}$ to $60^{\circ} \mathrm{E}$ dipping fault would produce the observed height changes. The theoretical displacement profiles fit the hanging-wall deformation pattern within $1.5 \mathrm{~km}$ of the fault to within $0.5 \mathrm{~mm}$. The observed seismicity lacks earthquakes of $M \geq 3$ that could produce this displacement. It is also noteworthy that a deepseated source is required to broaden the theoretical deformation profile wavelengths to match the footwall part of the signal.

If the observed height changes reported here are actually a manifestation of aseismic creep, then 
they constitute the first observation of vertical dipslip fault creep in the Basin Range province. The apparent creep rate of $3.3 \mathrm{~mm} / \mathrm{yr}$. is approximately 1.5 to 7 times greater than long-term Holocene slip rates, of 0.45 to $2.4 \mathrm{~mm} / \mathrm{yr}$. (Gilbert et al., 1983; Smith et al., 1993; Byrd, 1991; Byrd, 1995). If these are typical aseismic deformation rates, then a significant component of aseismic deformation should be factored into an evaluation of the earthquake hazards and long-term deformation across the Teton fault.

\section{$\downarrow$ ACKNOWLEDGMENTS}

Support for the leveling surveys were provided to the University of Utah by University of WyomingNational Park Service Research Center, grant 532724, U. S. Geological Survey, National Earthquake Hazards Reduction Program (NEHRP) grants 14-08-00001-G1349 and 14-08-0001-G1970; U. S. Geological Survey NEHRP grants 14-0800001-G1349 and 14-08-0001-G1970 to University of California, Santa Barbara; and University Research Expedition Programs grants in 1997 and 2001. We gratefully acknowledge the cooperation and logistical assistance of the Grand Teton National Park staff including superintendents Jack Stark and Jack Neckels; former assistant superintendent Marshall Gingery, environmental specialist Robert Schiller; their staff and the rangers at the Jenny Lake Ranger Station; to the staff of the University of Wyoming-National Park Service Research Center: Ken Diem, Mark Boyce, George Menkens, and Hank Harlow. We thank Emery Balazs (National Geodetic Survey), Fred Goodsell and Mike Beus (Bureau of Reclamation), and Charles Meertens (University of Utah and UNAVCO) for data and advice. The diligence and careful work of the University of California, Santa Barbara, and University of Utah undergraduate and graduate student surveying crews, together with that of the 1997 and 2001 UREP crews, is also greatly appreciated. Evelyn Roeloffs, U.S. Geological Survey, contribution to the hydraulic models was invaluable. Geoffrey King contributed the boundary element modeling program and important insights to fault modeling. A. R. Lowry, C. M. Meertens, and R. Stein also helped to clarify our evaluation and analysis of the data.

\section{REFERENCES CITED}

Byrd, J. O. D., Paleoseismicity of the southern section of the Teton fault, Wyoming, Geol. Soc. Amer. Abstr. Programs, 23, A481, 1991.

Byrd, J. O. D., Neotectonics of the Teton fault, Wyoming. Ph.D. dissertation, University of Utah, 295 p, 1995.

Byrd, J. O. D., and R. B. Smith, 1989. Bench mark descriptions: $1^{\text {st }}$-order leveling line, Cascade Canyon to Deadman's Bar, Grand Teton National Park, Wyoming. University of Wyoming - National Park Service Research Center project \#22, 23 p.

Castle, R. O., R. K. Mark, and R. H. Shaw, An empirical assessment of refraction error in leveling as a function of survey order and environment, U.S. Geological Survey Bulletin 2114, $50 \mathrm{p}$.

Federal Geodetic Commission, Standards and specifications for geodetic control networks, Nat. Geod. Surv., Rockville, Md, 31 p., 1984.

Gilbert, J. D., D. Ostenna, and C. Wood, Seismotectonic study Jackson Lake Dam and Reservoir, Minidoka Project, IdahoWyoming, Bur. Rec. Seismotectonic Report 83-8, 123 p, 1983.

Kahmen, H., and W. Faig, 1988. Surveying. Walter de Gruyter, New York, 578 p.

Karcz, I., J. Morreale, and F. Porebski, 1976. Assessment of bench credibility in the study of recent vertical crustal movements. Téctonophysics 33, T1-T6.

King, G. C. P., D. Oppenheimer, and F. Amelung, Block versus continuum deformation in the western United States, Earth and Planet.. Sci. Lett. 128, 55-64, 1994. 
Smith, R.B., J.O.D. Byrd, and D.D. Susong, Seismotectonics, Quaternary History, and Earthquake Hazards of the Teton fault, Wyoming, in Geology of Wyoming, Snoke, A., and Steidtmann, J.R., eds., Wy. Geol. Assoc. Pub., 1993.

Stein, R. S., Discrimination of tectonic displacement from slope-dependent errors in geodetic leveling from southern California, 19531979, pp. 441-456, in Earthquake Prediction: An International Review, Maurice Ewing Series, v. 4, edited by Simpson, D. W., and P. G. Richards. American Geophysical Union, Washington, D.C., 1981.

Sylvester, A.G., J.O.D. Byrd, and R.B. Smith, Geodetic evidence for aseismic reverse creep across the Teton normal fault, Geophys. Res. Lett., I8, 1083-1086, 1991.
Thatcher, W., G. R., Foulger, B. R. Julian, J. Svarc, E. Quilty, and G. W. Bawden, Present-day deformation across the Basin and Range Province, western United States, Science 283, 1714-1718, 1999.

Wernicke, R., A. M. Friedrich, N. A. Niemi, R. A. Bennett, and J. L. Davis, 2000. Dynamics of plate boundary fault systems from Basin and Range geodetic network (BARGEN) and geologic data. GSA Today 10 (11), 1-7.

Wesson, R., Dynamics of fault creep, J. Geophys. Res., 93, 8929-8951, 1988. 